\title{
Motivations of retired professors to return to work activities at a public university
}

Motivações de docentes aposentados ao retorno às atividades laborais em uma universidade pública

Ana Cláudia Souto Santos ${ }^{1}$, Benedita Gonçalves de Assis Ribeiro ${ }^{1}$, Júlia Trevisan Martins ${ }^{1}$, Maria José Quina Galdino $^{2}$, Maria Lúcia do Carmo Cruz Robazzi ${ }^{3}$, Renata Perfeito Ribeiro ${ }^{1}$

Objective: to understand the motivations of professors of a public university to return to teaching after retirement. Methods: qualitative study carried out with 13 professors at a public university who returned to work activities after they retired. Data were collected through semi-structured interviews and analyzed using content analysis. Results: four categories emerged: the feeling of missing the contact with students, financial increase, peak of career experiencing idleness and disease. Conclusion: professors return to the same labor activity after retirement because of desire to remain experiencing feelings of well-being that work promotes, as well as to prevent illness resulting from idleness.

Descriptors: Faculty; Retirement; Work.

Objetivo: compreender as motivações de docentes de uma universidade pública ao retornarem à docência após a aposentadoria. Métodos: estudo qualitativo realizado com 13 docentes de uma universidade pública, que retornaram às atividades laborais após estarem aposentados. Dados coletados por entrevistas semiestruturadas e analisados por meio da análise de conteúdo. Resultados: emergiram quatro categorias: saudades do contato com alunos, acréscimo financeiro, auge na carreira e vivenciando o ócio e a doença. Conclusão: os docentes retornaram para a mesma atividade laboral após a aposentadoria pelo desejo de permanecer vivenciando os sentimentos de bem-estar que o trabalho proporciona, bem como prevenir o adoecimento decorrente de sua falta.

Descritores: Docentes; Aposentadoria; Trabalho.

\footnotetext{
${ }^{1}$ Universidade Estadual de Londrina. Londrina, PR, Brazil.

${ }^{2}$ Universidade Estadual do Norte do Paraná. Bandeirantes, PR, Brazil.

${ }^{3}$ Universidade de São Paulo. Ribeirão Preto, SP, Brazil. 


\section{Introduction}

Population aging is a global event that has taken place in a systematic and consistent manner. In Brazil, the changes in the population pyramid show that the number of individuals aged at 60 years or older has increased from $4.8 \%$ in $1991,5.8 \%$ in 2000 and $7.4 \%$ in 2010 to $12.0 \%$ in 2015 . The prospect is, therefore, that this population correspond to $22.0 \%$ in $2030^{(1)}$.

Growing old is a natural and it is a long process. During this process, changes occur and they require constant adaptation. These are faced with ease $y$ many people, but for others, they might represent an obstacle. In this sense, retirement is often linked to inactivity and is related to the emergence of problems of physical and emotional nature, such as selfdeprecation, decreased self-esteem, dissatisfaction, apathy, discouragement, loneliness, social withdrawal, chronic degenerative diseases, among others, and all of these diminish the quality of life $\mathrm{e}^{(2-3)}$.

Such consequences may have roots in the capitalist system, in which the economic value and production are the rulers, and the elderly are relegated as of little relevance. They hardly reenter the labor market because they are considered "fragile, unproductive and obsolete" by the vast majority of society, being replaced by young people who are favored with updated knowledge and better conditions, especially physical, to the exercise of professional activities ${ }^{(4)}$.

However, the National Survey by Household Samples shows that in the 1970s and 1990s, Brazilian elderly had high participation in the labor market compared with international standards, a fact that is directly related to the return of retired people to work. Between 2006 and 2013 there was an increase of $9.4 \%$ in the number of economically active retired people; these data indicate that this fraction of retired people was always above $30.0 \%$ during the analyzed $\operatorname{period}^{(5)}$.
Among the factors that lead people the decision of returning to work activities after retirement is the wage supplement, mainly. However, the maintenance of the link also comes from the desire for recognition and to continue feeling useful in a social group, guided by the productive value ${ }^{(6)}$.

This is because the work is seen as a duty of the human being, and it is through it that man produces and reproduces. Thus, the elderly also feel the desire to remain or re-enter in the labor exercise because this is a personal achievement, because of increased selfesteem due to social recognition and assertive selfimage originated from a professional performance with quality, as the work is a way to use the time and establish interpersonal relationships. However, in addition to the own will, society also requires that they produce, so that they may not become a "burden" or have an occupation and an area of freedom ${ }^{(7-8)}$.

In this sense, the teaching profession is also permeated by feelings of recognition and professional achievement, development of affective relationships with co-workers and students, among others. In addition, satisfaction in the teaching profession is closely related to the generated product: professionals with scientific knowledge and philosophical and technical skills and able to meet the demands of the labor market ${ }^{(9)}$. Thus, the desire to remain in a profession with so meaningful experiences of pleasure and satisfaction is expected.

Given the above, it is clear that retirement is a unique step in the lives of people, in which individuals will experience a new situation, causing new feelings and situations to be faced. Thus, it is believed that by investigating the motivation of professors to return to work activities after retirement may provide base for the implementation of Programs of Preparation for facing retirement for professors and consequently contribute to the physical, mental and psychosocial well-being in this new stage of life of these individuals, who are key elements in the area of health and nursing 
to generating knowledge. Additionally, the study may incentive professors to reflect on the importance of planning and preparing for retirement, as it is necessary that people understand the process of transition and have confidence and clarity about their choices at the right time.

In view of the above, the following research question is raised: What are the reasons that lead professors, after retirement, to return to their previous professional activities? To answer this question, this study aimed to understand the motivations of professors of a public university to return to teaching after retirement.

\section{Methods}

This is a qualitative research that sought to deepen the understanding on the phenomenon to be investigated, with emphasis on the processes experienced by people ${ }^{(10)}$.

The study population consisted of retired professors from different areas of knowledge that had turned to their work activities in a public university of northern Paraná, Brazil. The criteria for inclusion of participants were: be a retired professors, have returned to work as a professor through public selection and up to the third attempt to schedule.

To identify possible participants, the Dean of Human Resources of the University provided a list of the names of all retired professors that had returned to work activities after applying in public selections, totaling 27 professors.

To determine the number of participants, we used the criterion of saturation of the lines. Thus, interviews were conducted until the moment when there was recurrence of information regarding the studied phenomenon, always considering the unique aspects in the information provided by respondents ${ }^{(10)}$, what occurred with 13 professors. It is noteworthy that among the contacted professors, there was no refusal to participate.
The data collection technique adopted was semi-structured interview, with questions to characterize the research participants related to gender, age, title, area of expertise, working time in that university and time after retirement and return to work. To reveal the object of study, we used the following guiding question: what motivations led you to return to work as a professor after retirement?

The interviews were conducted individually in the setting of the study, that is, in the rooms of each participant. Interviews were previously scheduled by phone and took place between June and September 2015. The interviews were recorded in audio with the permission of the participants and lasted about thirty minutes.

Data from reports of the interviews were analyzed using content analysis technique, in the thematic modality, in which we sought to find the units of meaning that constitute the communication, that is, the presence or frequency to express something to the analytic object to be investigated. Thus, the process of data analysis was carried out in three stages: the first was the pre-analysis, with the completion of the initial reading of the speeches, organization of the "corpus", as the material was thoroughly explored with representativeness and homogeneity. At this stage, also, the units of registration were determined, the units of context, the excerpts, the way of categorization, the modality of coding and general theoretical definitions to guide the analyzes; in the second stage, exploration of material was carried out, to sort the content in order to reach the core of understanding of the text and sort the categories that represent the expressions, words and characteristics that surfaced the narratives of the professors; finally, in the third stage consisted in the processing and interpretation of results ${ }^{(10)}$.

The study complied with the formal requirements contained in the national and international regulatory standards of research involving human beings. 


\section{Results}

Among the participants, nine were male and four were females, aged between 60 and 64 years and all with a PhD degree. Most of them exercised activities as professor at the university for more than 32 years and the time spent between retirement and returning to activities through public selection was on average three years. As for the area of expertise, participants were acting in the following professional categories: nursing, medicine, biomedicine, psychology, mathematics, statistics and geography.

From the identification of units of registration, themes were grouped into four categories, as summarized below:

\section{Feelings of missing the contact with students}

In this category, it was seized that professors returned activities after being retired because of feelings of missing being in contact with students, as identified in the reports: I came back mainly because I felt really I missed being with the students, it was a feeling of something was missing, that I cannot even describe (P3). I never thought I'd feel like this, missing my students so much. I think we discover this feeling of missing only after getting away from them(D6). I have several reasons to be back, but I really like to be with the students, I felt a void when I was without them. The feeling of missing was huge, then I decided, I did the selection and I'm here (P8). I admit that the longing of being everyday with the students made me reflect and decide to return to the teaching activities. I felt a huge feeling of missing them, and I couldn't bear being without them ... Then I decided to return (P11).

\section{Financial increase}

The professors realized that returning to teaching activities after retirement represented a possibility to increase the financial income, which they considered insufficient if coming only from retirement. Of course I like to be a professor, but what motivated me to return to my activities was the possibility to increase my earnings. We always had small income that is no secret to anyone and then I saw an opportunity to increase it (P1). All favored my return, but as is permitted by law for us to return after being retired, I did not hesitate to go through the selection again and come back, because I saw a real chance to increase my financial conditions (P9). Everyone knows we always earned very little and my return was an opportunity to increase my income and have a better quality of life. I'm sure I did not do anything illegal, the government allows we to resume work, then I did the public slection along with other candidates (P13).

\section{Peak of career}

The possibility of retired professionals returning to the labor market is increasingly present in our society. They return mainly to the same profession or the same activities, the return happens because people feel that they have acquired and accumulated knowledge along the years of professional practice and this must be shared with others, that is, these professionals still have contributions to make. The lines express this understanding: We were in the phase of implementing the master's course and I always said it was a dream of mine not getting retired before first opening a master's course. I was at the peak of my career so I decided to come back (P2). I was and I am still at the peak of my career, guiding students in master's and doctorate and publishing scientific papers. That was the fundamental reason for my return(P4). After retirement, I realized I had still much to contribute. I was at the peak of my career, with this understanding, I decided to go through the selection again and return to my activities in full swing (P5).

\section{Experiencing idleness and disease}

The work is important for people as identity, as an opportunity of growth, recognition, feeling of being useful, among other factors. However, in the case of respondents, the importance to these aspects was perceived only after the experience of leaving the 
world of work. Wow! The experience of staying at home was bad, doing nothing was a feeling of emptiness, that something was missing in my life. This was the reason that made me return to my activities as a professor at the university (P3). It was a hole, a void that nothing filled, I sought other activities, but what I really wanted was to go back to teaching and then I returned (P12).

The work can help to promote health, but it needs to be done in accordance with the real needs of people, because on the contrary, this can result in pain and trigger diseases of many kinds. Recognition of the importance of work for the health of the participants is evident in the speeches: I started to get depressed, unhappy, I was getting sick for lack of work (P7). How would I cope with the depression that settled in my life after retirement? I found out how much work is a promoter of my health and that was the reason why I came back (P10).

\section{Discussion}

Although the study objectives were achieved, there were limitations due to the fact that collection was held with retired professors of only one public university. Another limitation is the lack of research on this subject that makes difficult to discuss it with more recent studies. Thus, the development of further research on longevity of the population and retirement is suggested, as well as on how managers and workers need to plan to face this reality.

The findings of this research collaborate to advance the knowledge in the areas of health and nursing, as they provide base for implementation or adaptation of Programs of Preparation for Retirement. It is necessary that these programs be conducted for all professors, focusing on the interfaces of this new stage of life and showing the freedom that people have to decide and control their own lives, but with responsibility and respect for others.

We must be very well prepared to retire, because many are the problems faced by professors who do not prepare for this stage of life. Retiring is not simply cutting the link with the professional environment and work, but also to lose contact with an environment of exchange of knowledge, experiences, pleasure, challenges, friendships, relationships, among others, causing many to return to work ${ }^{(11)}$.

Retirement is a stage where people finish the activities that have been developed over a long period in their lives, and this disruption may cause feelings such as grief, loss of self-esteem, loss of identity, nostalgia of experiences, fear of losing friends, or fear that social relationships are disrupted. Thus, it is important to make plans aimed at preparing individuals for this new condition. It is also necessary to promote social support from external sources as well as from the institution in order to minimize the anxiety and the fear of social exclusion arising from retirement ${ }^{(12)}$.

In this study, it was found that the lack of social relationship with students was one of the motivations for professors to return to work activity, what may be related to positive memories of this bond. The studentprofessor relationship is one of the expressions of job satisfaction because it is in the interaction with the students that the professor transmits knowledge and accompanies the growth of the students, as well as have the work acknowledged by students ${ }^{(9)}$.

The financial increase caused by the employment and the monetary values of the retiree benefit was indicated by respondents as an opportunity to have better living conditions. These findings are similar to a survey carried out with retired professors by revealing that the return to work after retirement was motivated by the opportunity to improve the quality of life, as the income from two salaries provide a chance to fulfill some wishes that were not possible with low wages ${ }^{(13)}$.

From another perspective, the financial situation leads professors to return to work after retirement, because the income does not give them the possibility of realize some dreams, like traveling 
and sightseeing. Thus, accumulating earnings coming from retirement and from the salary of active professor can contribute to achieving some of these goals ${ }^{(14)}$.

The financial gains that come from returning to work after retirement is a reality. However, subjective factors are the main causes for maintaining the link with the work, since feelings being useful, recognized and valuable come from this link. Such values are crystallized in society, making it difficult for people to understand that life is more than a production coming from labor activity ${ }^{(15)}$.

However, the incentive to most experienced professors to remain in their professional activities is a reality in other countries. Professors with more advanced ages are encouraged to stay in the profession by offering them part-time works and reduction of working hours without jeopardizing their long-term employment and their pension rights. Although Brazil lack such incentives, the legislation provides that any professional can enjoy the right to stay at work or return to it after retirement and for indefinite time ${ }^{(16-17)}$.

The ability to share teaching experience gained over the years and contribute to the training of professionals was also mentioned by participants as one of the motivating factors for returning to work. Individual aspects are present among the reasons for the return to work, such as the need to update and feel productive. However, interpersonal reasons such as the need to get along with others and pass on the knowledge and the accumulated experience during work activities was highlighted by respondents ${ }^{(18)}$.

Regarding the feeling of emptiness caused by the lack of teaching work, a research added that being retired can arouse feelings of worthlessness, and the fear of no longer participate in activities considered important to society, reflecting on feelings of worthlessness that, in turn, generate emptiness and the sensation that something is missing, making professionals to eventually return to work activities ${ }^{(19)}$.
Retirement may mean the loss of meaning of life for a large portion of people, or a kind of social death because of the distance from the work that was a place that promotes social and emotional relationships. Thus, the absence of this bond promotes, in some cases, the onset of anxiety, depression and other mental disorders in the long term can unfold into physical problems ${ }^{(11)}$.

The professors participating in this study showed that the strategy used to prevent this mental illness was the return to work. The understanding of the people that health can be maintained through work has become a determining factor for people to remain in the working world, as well as to return to work activities after retirement ${ }^{(4)}$.

There is a positive relationship between enjoying better health condition and the exercise of work since independence and physical flexibility and mental aspects are preserved. In turn, inactivity has been linked to poorer health, higher mortality rates and high prevalence of psychiatric symptoms, high blood pressure and alcohol consumption ${ }^{(8-9)}$.

Thus, it is noteworthy that it is necessary to make plans for retirement, so that in the time to enjoy it, people may not be affected by anxiety, loneliness, depression and discouragement resulting from difficulties to experience feelings of pleasure and personal fulfillment coming from work, even if such work activities were permeated by suffering at times, because no work is free from feelings of pleasure and pain $^{(20)}$.

It is essential that professors, whether in the nursing area or not, prepare for retirement, since this can represent a singular moment that may have a meaning that is beyond the end of a career. Planning and preparing for the moment of retirement help to clarify and to make sure that when this finaly happens, the person may be able to seize it and experience it in every sense. 


\section{Conclusion}

This study led to the conclusion that the reasons that make professors to return to the previous work activities are related to material, psychological and social needs, the lack of social interaction with students, the possibility of increasing income and having better quality of life, the feeling that tey can still contribute with their accumulated knowledge during the long period of professional practice, besides the void that cannot be filled and problems of psychological nature, such as anxiety and depression that affected some of the participants.

\section{Collaborations}

Santos ACS and Ribeiro BGA contributed to the planning and design of the project, analysis and interpretation of data, writing and final approval of the version to be published. Martins JT, Galdino MJQ, Robazzi MLCC and Ribeiro RP contributed to interpretation of data, writing of the article and final approval of the version to be published.

\section{References}

1. Instituto Brasileiro de Geografia e Estatística. Mudança demográfica no Brasil no início do século XXI. Subsídios para as projeções da população [Internet]. 2015 [citado 2016 mar 03]. Disponível em: http://biblioteca.ibge.gov.br/visualizacao/ livros/liv93322.pdf

2. Martins JT, Bobroff MCC, Ribeiro RP, Gaspar SG, Basani AB, Stanganelli NC. Retirement: meanings for nursing professionals. Rev Enferm UFPE on line [Internet]. 2014 [cited 2016 Mar 03]; 8(5):1323-9. Available from: http://www.revista. ufpe.br/revistaenfermagem/index.php/revista/ article/view/4933/pdf_5102

3. Reis CB, Jesus RS, Silva CSO, Pinho L. Health conditions of young and old elderly. Rev Rene. 2016; 17(1):120-7.
4. Guimarães DBO, Figueiredo MLF, Beleza CMF. Determinants for the (re)integration of the elderly population in the labor market. Rev Enferm UFPI. 2013; 2(4):78-82.

5. Instituto Brasileiro de Geografia e Estatística. Pesquisa Nacional por Amostras de Domicílios [Internet]. 2013 [citado 2016 abr 21]. Disponível em:http://biblioteca.ibge.gov.br/visualizacao/ periodicos/59/pnad_2013_v33_br.pdf

6. Khoury HT, Ferreira A, Souza R, Matos A, Barbagelata-Góes $\mathrm{S}$. Why retired come back to work? The role of psychosocial factors. Rev Kairós Gerontol. 2010; 13(1):147-65.

7. Souza RF, Matias HA, Brêtas ACP. Reflexions about aging and work. Ciênc Saúde Coletiva. 2010; 15(6):2835-43.

8. Panozzo EAL, Monteiro JK. Retirement and mental health: a literature review. Cad Psicol Soc Trab. 2013; 16(2):199-209.

9. Lemos MC, Passos JP. Satisfaction and frustration in the performance of nursing faculty job. Rev Min Enferm. 2012; 16(1):48-55.

10. Bardin L. Análise de conteúdo. Lisboa: Edições 70; 2011.

11. Stano RCT. Identidade do professor no envelhecimento. São Paulo: Cortez; 2001.

12. Osborne JW. Existential and psychological aspects of the transition to retirement. Eur J Psychother Couns. 2012; 14(4):1-15.

13. Meira VRA, Leite YUF. What leads retired teachers to return to teaching? Nuances Est Educ. 2015; 26(1):219-33.

14. Dartora CM. Aposentadoria do professor: aspectos controvertidos. Curitiba: Juruá; 2009.

15. Mandres M. Out of the labour market: Intra-EU return and retirement migration. In: WaltonRoberts M, HennebryJ. Territoriality and Migration in the E.U. Neighbourhood. Netherlands: Springer; 2014. p.163-91.

16. Moulaert T, Biggs S. International and European policy on work and retirement: Reinventing critical perspectives on active ageing and mature identity. Hum Relations. 2013; 66(1):25-45. 
17. Organização para Cooperação e Desenvolvimento Econômico. Professores são importantes: atraindo, desenvolvendo e retendo professores eficazes. São Paulo: Moderna; 2006.

18. Ferreira AJC, Matos AP, Araújo D, Souza RA, Barbagelata-Góes S, Khoury HTT. Retorno ao trabalho remunerado entre aposentados: Alguns fatores psicossociais. Pará: Universidade Federal do Pará; 2005.
19. Liberatti VM, Martins JT, Robazzi MLCC, Cardelli AAM, Gvozd R, Trevisan GS. Social representations of retirement for nurses teaching at one public university. Rev Enferm UFPE on line [Internet]. 2015; [cited 2016 Mar 13]; 9(11):9699-705. Available from: http://www.revista.ufpe.br/ revistaenfermagem/index.php/revista/article/ view/7467/pdf_8806

20. Dejours C, Abdoucheli E, Jayet C. Psicodinâmica do trabalho: contribuições da escola de dejouriana à análise da relação prazer, sofrimento e trabalho. São Paulo: Atlas; 2014. 